\title{
Gastrointestinal parasites of exotic birds living in captivity in the state of Sergipe, Northeastern Brazil
}

Parasitos gastrointestinais de aves exóticas que vivem em cativeiro no estado de Sergipe, Nordeste do Brasil

\author{
Victor Fernando Santana Lima ${ }^{1 *}$; Taynar Lima Bezerra²; Alex Fonseca de Andrade ${ }^{2}$; \\ Rafael Antonio Nascimento Ramos ${ }^{3}$; Maria Aparecida da Glória Faustino ${ }^{1}$; Leucio Câmara Alves \\ Patrícia Oliveira Meira-Santos ${ }^{2}$
}

${ }^{1}$ Departamento de Medicina Veterinária, Universidade Federal Rural de Pernambuco - UFRPE, Recife, PE, Brasil

${ }^{2}$ Departamento de Medicina Veterinária, Universidade Federal de Sergipe - UFS, São Cristóvão, SE, Brasil

${ }^{3}$ Unidade Acadêmica de Garanhuns, Universidade Federal Rural de Pernambuco - UFRPE, Garanhuns, PE, Brasil

Received June 28, 2016

Accepted October 27, 2016

\begin{abstract}
Brazil has a wide diversity of exotic birds that were brought to this country during the European colonization. These animals are kept in captivity and, in some cases, in inadequate facilities, which may facilitate the introduction of pathogens, including gastrointestinal parasites. The purpose of this study was to identify the main gastrointestinal parasites that affect exotic birds living in captivity in the state of Sergipe, Northeastern Brazil. Fecal samples $(n=362)$ from exotic birds were analyzed by direct examination and by the Willis-Mollay technique. Eggs of Amidostomum sp., Ascaridia sp., Capillarinae, Heterakis sp., Trichostrongylidae, and oocysts of coccidians were identified in nine different bird species. This is the first report in Brazil of infection by Ascaridia sp. and Heterakis sp. in Nymphicus hollandicus; by Trichostrongylidae in Serinus canaria and Streptopelia risoria.
\end{abstract}

Keywords: Columbiformes birds, Amidostomum, Ascaridia, Heterakis, Trichostrongylidae.

\section{Resumo}

O Brasil possui uma grande diversidade de aves exóticas que foram trazidas para o país durante a colonização europeia. Estes animais são mantidos em cativeiros, os quais muitas vezes são inadequados, proporcionando o surgimento de doenças provocadas por parasitas gastrointestinais. Objetivou-se neste estudo, realizar avaliação coproparasitológica de fezes de aves ornamentais mantidas em cativeiros no estado de Sergipe, regiáo Nordeste do Brasil. Amostras fecais $(\mathrm{n}=362)$ de aves exóticas foram analisadas através do exame direto a fresco e técnica de Willis-Mollay. Ovos de Amidostomum sp., Ascaridia sp., Capillarinae, Heterakis sp., Trichostrongylidae, e oocistos de coccídeos foram encontrados em nove diferentes espécies de aves. Aqui, destacamos, os primeiros registros no Brasil de Ascaridia sp. e Heterakis sp., parasitando Nymphicus hollandicus; Trichostrongilidae em Serinus canaria e Streptopelia risoria.

Palavras-chave: Aves columbiformes, Amidostomum, Ascaridia, Heterakis, Trichostrongylidae.

Several exotic bird species, especially some originating from Europe, were introduced into Brazil in the $16^{\text {th }}$ century, and became well adapted to the conditions of their new environment (AMAE, 2013).

Today, these bird species are kept in captivity during part of or their entire life. In captivity, these animals need a comfortable environment, free of stress, predators and disease, with sufficient space to fly freely, and high quality bird feed (SANTOS et al., 2008). However, inadequate facilities may facilitate the introduction of pathogens such as gastrointestinal nematodes and coccids, which cause different clinical manifestations (MARIETTO-GONÇALVES et al.,

*Corresponding author: Victor Fernando Santana Lima. Universidade Federal Rural de Pernambuco - UFRPE, Rua Dom Manoel de Medeiros, s/n, Dois Irmãos, CEP 52171-900, Recife, PE, Brasil. e-mail: victor.fslima@gmail.com
2009). In general, birds infected with gastrointestinal parasites present diarrhea, apathy, prostration, abdominal enlargement and neurological signs, which, if left untreated, may lead to death (JOSEPH, 2003; GOMES et al., 2009; AGUIAR \& LUCIANO, 2011).

Inadequate management of these animals, as well as lack of information of their owners, contributes to the occurrence of these parasitic diseases, which are often diagnosed only during postmortem examination (MARIETTO-GONÇALVES et al., 2009; GOMES et al., 2009). For this reason, information for coproparasitological diagnosis is still limited, which may hinder the in vivo detection of eggs and/or oocysts. Therefore, the purpose of this study was to identify the main gastrointestinal parasites that affect exotic birds living in the state of Sergipe, Northeastern Brazil. 
From January to August 2014, pool fecal samples ( $\mathrm{n}=32$ ) were collected from exotic birds ( $\mathrm{n}=362$ ) of different species, ages and gender. The birds used in this study belonged to three different Orders: Columbiformes $(\mathrm{n}=109)$, Psittaciformes $(\mathrm{n}=197)$ and Passeriformes $(\mathrm{n}=56)$ (Table 1$)$. The animals were distributed in 32 cages of iron $(150 \mathrm{~cm} \times 100 \mathrm{~cm} \times 100 \mathrm{~cm})$, containing a double-feeder and a single water cooler drinking fountain, where about 12 birds of the same species were kept. They were fed with grains, fruits and vegetables. These animals were from six private commercial breeding located in the municipalities of metropolitan region of Aracaju, in the state of Sergipe, northeastern Brazil.

All samples were collected only after the responsible for each breeding facility signed a Free and Informed Consent Form. All the birds' case histories were recorded and they were subjected to a physical examination, and pooled fecal samples were collected $(n=32)$ from the floor of each cage. The fecal material was placed in plastic bags, labeled and stored at $8{ }^{\circ} \mathrm{C}$ for later laboratory processing.

Each pool was analyzed individually by three copromicroscopic methods: i) direct examination, ii) the Willis-Mollay technique and iii) spontaneous sedimentation of Hoffman, Pons and Janer.

Table 1 lists the different exotic bird species assessed in this study. Gastrointestinal parasites were detected in 69\% (22/32) of the analyzed pools; $73 \%(16 / 22)$ of the positive samples were positive for nematode eggs and 60\% (13/22) for unsporulated oocysts. In particular, $36.4 \%$ (8/22) were detected through the direct examination, $77.3 \%(17 / 22)$ by the method of Hoffman, Pons and Janer, and $95.5 \%(21 / 22)$ by the Willis-Mollay technique. Eggs of
Heterakis sp., Amidostomum sp., Trichostrongylidae, Ascaridia sp., Capillarinae, and unsporulated oocysts herein detected are shown in Table 2 and Figure 1.

Co-infections were detected in $45 \%$ (10/22) of the positive samples, with some samples showing more than five types of co-infections. The most frequent co-infections were Trichostrongylidae + Capillarinae + Coccidians (27.2\%), then Capillarinae + Ascaridia sp. + Coccidians (18.2\%), Trichostrongylidae + Ascaridia sp. + Coccidians (9.1\%), Trichostrongylidae + Coccidians (9.1\%), Ascaridia sp. + Heterakis sp. (9.1\%), and Ascaridia sp. + Coccidians (9.1\%).

The largest number of positive samples $(59 \% ; 13 / 22)$ was found in the order Columbiformes. On the other hand, the positivity rates found in the Psittacidae, Cacatuidae, Fringillidae and Estrildidae families were $13.6 \%(3 / 22), 13.6 \%(3 / 22), 9.3 \%(2 / 22)$, and $4.5 \%$ $(1 / 22)$, respectively. All eggs and oocysts were identified based on morphological features provided in Bowman et al. (2006) and Taylor et al. (2010).

This research involved a study of the gastrointestinal parasite fauna of exotic birds living in northeastern Brazil. The overall positivity rate $(69 \% ; 22 / 32)$ reported here was higher than rates detected in previous studies. For instance, a study conducted in the state of Paraná, Brazil, reported a prevalence of gastrointestinal parasites of 54\% (127/228) in fecal samples of wild birds using the Hoffman sedimentation technique and the Willis flotation method as diagnostic tools (SNAK et al., 2014). Conversely, a low positivity rate $(19.6 \%$; 40/207) was detected in exotic birds in the state of São Paulo (MARIETTO-GONÇALVES et al., 2009). It is important to note that the differences in positivity

Table 1. Taxonomic classification, origin and number of specimens evaluated.

\begin{tabular}{|c|c|c|c|c|}
\hline Order & Familie & Scientific name & Place of origin & Number of specimens \\
\hline \multirow{3}{*}{ Columbiformes } & \multirow{3}{*}{ Columbidae } & Columba livia (Gmelin, 1789) & Africa, Asia e Europe & 74 \\
\hline & & Geopelia cuneata (Latham, 1801) & Oceania & 08 \\
\hline & & Streptopelia risoria (Linnaeus, 1758) & Africa & 27 \\
\hline \multirow{3}{*}{ Psittaciformes } & \multirow{2}{*}{ Psittacidae } & Melopsittacus undulatus (Shaw, 1805) & Oceania & 131 \\
\hline & & Agapornis fischeris (Reichenow, 1887) & Africa & 19 \\
\hline & Cacatuidae & Nymphicus hollandicus (Kerr, 1792) & Oceania & 47 \\
\hline \multirow{3}{*}{ Passeriformes } & \multirow{2}{*}{ Fringilidae } & Poephila guttata (Reichenbach, 1862) & Africa and Oceania & 15 \\
\hline & & Serinus canaria (Linnaeus, 1758) & Europe & 18 \\
\hline & Estrildidae & Lonchura oryzivora (Linnaeus, 1758) & Asia e Oceania & 23 \\
\hline Total & & & & 362 \\
\hline
\end{tabular}

Table 2. Number of positive pools for bird species.

\begin{tabular}{|c|c|c|c|c|c|c|c|}
\hline Scientific name & $\begin{array}{c}\text { Positive } \\
\text { pools }\end{array}$ & Ascaridia sp. & Capillarinae & Trichostrongylidae & Amidostomum sp. & Heterakis sp. & Coccidians \\
\hline Streptopelia risoria & 03 & - & - & 02 & 01 & - & 02 \\
\hline Columba livia & 10 & 05 & 10 & 03 & 01 & - & 04 \\
\hline Melopsittacus undulates & 01 & - & - & - & - & - & 01 \\
\hline Agapornis fischeris & 02 & 02 & 01 & - & - & - & 01 \\
\hline Nymphicus hollandicus & 03 & 01 & - & - & - & 02 & 01 \\
\hline Poephila guttata & 01 & - & - & - & - & - & 01 \\
\hline Serinus canaria & 01 & - & - & 01 & - & - & 01 \\
\hline Lonchura oryzivora & 01 & - & - & - & - & - & 01 \\
\hline Absolute Frequency (n) & 22 & 08 & 11 & 06 & 02 & 02 & 12 \\
\hline Relative Frequency (\%) & 100 & 36.5 & 50 & 27.2 & 9.1 & 9.1 & 54.5 \\
\hline
\end{tabular}




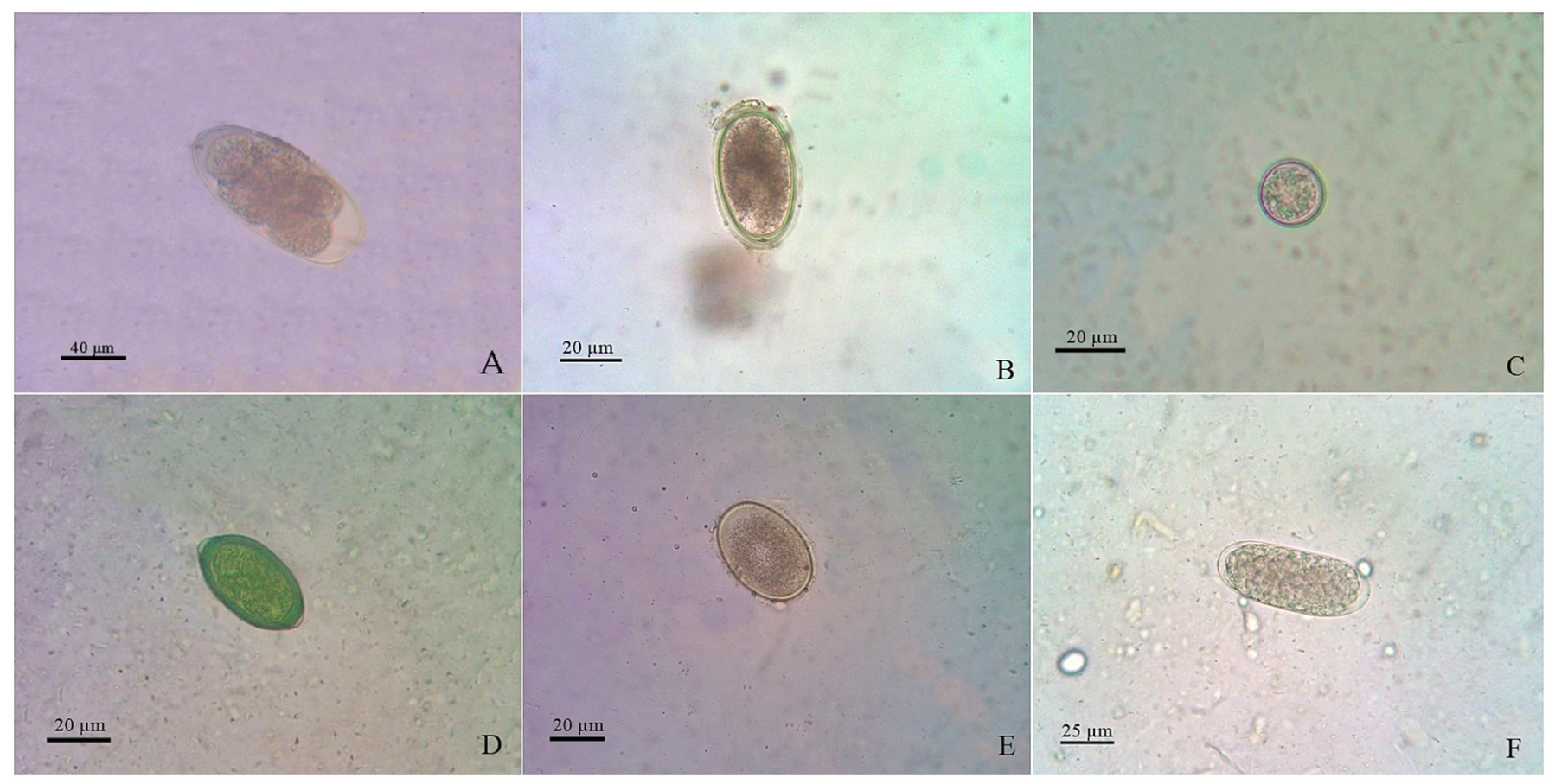

Figure 1. Eggs of gastrointestinal parasites detected in exotic birds. (A) Egg of Amidostomum sp.; (B) Egg of Ascaridia sp.; (C) Oocyst of coccidia unsporulated; (D) Egg of Capillarinae; (E) Egg of Heterakis sp. and (F) Egg of Trichostrongylidae.

rates found in distinct studies may be attributed to the sensitivity and specificity of the copromicroscopic technique, as well as the parasitic load of each animal (SANTOS et al., 2008; COSTA et al., 2010). In addition, proper sample collection and conservation are essential to avoid misdiagnosis, and consequently different results (SNAK et al., 2014).

The parasites most frequently found in this study were Ascaridia sp., Capillarinae, Trichostrongylidae and coccids. These species are among the most common gastrointestinal parasites of exotic birds living in captivity (FREITAS et al., 2002). Ascaridia sp., Capillarinae and Trichostrongylidae are parasites frequently reported in the gastrointestinal tract of birds, mainly immunosuppressed Columbiformes and Psittaciformes (FREITAS et al., 2002; MARQUES et al., 2007). Similarly, coccid species, especially those belonging to the genera Eimeria and Isospora, have been detected extensively parasitizing birds, being the coccidiosis is recognized as the parasitic disease that has the greatest economic impact on poultry production, due to mortality, morbidity, and poor feed conversions of birds, representing the annual worldwide cost is estimated at about $\$ 800$ million (WILLIAMS, 1998; ALLEN \& FETTERER, 2002; CARNEIRO et al., 2011). This study detected, for the first time, Nymphicus hollandicus parasitized by Ascaridia sp. plus Heterakis sp., and Serinus canaria and Streptopelia risoria parasitized by Trichostrongylidae.

Another noteworthy finding is the identification of Amidostomum sp. eggs in fecal samples of S. risoria and Columba livia. Although this parasite has rarely been detected in Brazilian birds, it is frequently reported parasitizing wild ducks in Europe (KAVETSKA et al., 2011). In South America, the occurrence of this parasite species has been reported in wild birds living in captivity in Colombia (CORREDOR et al., 2013).
From an epidemiological standpoint, helminthic (e.g., Ascaridia sp.) and protozoan (e.g., coccidians) infections pose a serious threat to the health of commercially bred exotic birds, especially when they present high parasitic loads and clinical signs such as diarrhea, weight loss, apathy, reproductive disorders and death (VICENTE et al., 1995; MARIETTO-GONÇALVES et al., 2009; AMARAL \& OTUTUMI, 2013). It should be noted that although some nematode species (e.g., Heterakis sp.) are considered of minor pathogenic importance, sudden death has been reported frequently in recent years (SANTOS et al., 2008).

In fact, it is known that the presence of gastrointestinal parasites in commercially bred birds is often related to the absence of a quarantine period. In addition, the size of breeding facilities, type of floor, population density in each cage, and absence of diagnostic and treatment protocols, contribute to the introduction and dissemination of gastrointestinal parasites (MARIETTO-GONÇALVES et al., 2009; FIGUEIREDO et al., 2010; SNAK et al., 2014).

This study identifies the gastrointestinal parasites of exotic birds living in state of Sergipe, northeastern Brazil and offers the first report of parasitism of $N$. hollandicus by Ascaridia sp. and Heterakis sp., of $S$. canaria and $S$. risoria by Trichostrongylidae in this country.

\section{References}

Aguiar MB, Luciano L. Risks of contamination related to the overpopulation of Columba livia (pigeons) in dock work. Rev Bras Pesq Saúde 2011; 13(3): 43-49.

Allen PC, Fetterer RH. Recent advances in biology and immunobiology of Eimeria species and in diagnosis and control of infection with these 
coccidian parasites of poultry. Clin Microbiol Rev 2002; 15(1): 58-65. PMid:11781266. http://dx.doi.org/10.1128/CMR.15.1.58-65.2002.

Amaral PFGP, Otutumi LK. Prevalence of coccidiosis in broiler in a poultry integration in the Northwest Region of the State of Paraná, Brazil. Enc Biosf 2013; 9(16): 1759-1768.

Associação Mineira de Aves Exóticas - AMAE. Artigos [online]. Belo Horizonte: AMAE; 2013 [cited 2016 Mar 10]. Available from: http:// www.amaemg.com.br/index.php/pt/ct-menu-item-18

Bowman DD, Lynn RC, Eberhard ML, Alcaraz A. Parasitologia veterinária de Georgis. 8th ed. São Paulo: Elsevier; 2006.

Carneiro MB, Calais Júnior A, Martins IVF. Coproparasitological and clinical evaluation of particular birds in Alegre-ES, Brazil. Cienc Anim Bras 2011; 12(3): 525-529.

Corredor DJG, Parada OJS, Medellín MOP, Becerra RJA. Identificación de parásitos gastrointestinales en aves silvestres en cautiverio. Rev Cie Univer del Zulia 2013; 23(3): 254-258.

Costa IA, Coelho CD, Bueno C, Ferreira I, Freira RB. Gastrintestinal parasitic occurrence in wild birds captured in Seropedica city at Rio de Janeiro state, Brazil. Cienc Anim Bras 2010; 11(4): 914-922.

Figueiredo MAP, Santos ACG, Guerra RMSNC. Ectoparasites of wild animals in Maranhão. Pesq Vet Bras 2010; 30(11): 988-990. http://dx.doi. org/10.1590/S0100-736X2010001100013.

Freitas MFL, Oliveira JB, Cavalcanti MDB, Leite AS, Magalhaes VS, Oliveira RA, et al. Gastrointestinal parasites of captive wild birds in Pernambuco state, Brazil. Parasitol Latinoam 2002; 57(1-2): 50-54.

Gomes FF, Machado HHS, Lemos LS, Almeida LG, Daher RF. Main intestinal parasites diagnosed in domestic chickens raised in extensive regimen in the municipality of Campos dos Goytacazes, RJ. Cienc Anim Bras 2009; 10(3): 818-822.
Joseph V. Infectious and parasitic diseases of captive passerines. Sem Avian Exot Pet Med 2003; 12(1): 21-28. http://dx.doi.org/10.1053/ saep.2003.127878.

Kavetska KM, Królaczyk K, Stapf A, Grzesiak W, Kalisińska E, Pilarczyk B. Revision of the species complex Amidostomum acutum (Lundahl, 1848) (Nematoda: Amidostomatidae). Parasitol Res 2011; 109(1): 105117. PMid:21234601. http://dx.doi.org/10.1007/s00436-010-2233-z.

Marietto-Gonçalves GA, Martins TF, Lima ET, Lopes RS, Andreatti Filho RL. Prevalence of endoparasites in fecal samples of exotic and wild birds examined in the Laboratory of Ornitopatology and Laboratory of Parasitics Diseases of the FMVZ-UNESP/Botucatu, SP. Cienc Anim Bras 2009; 10(1): 349-354.

Marques SMT, Cuadros RM, Silva CJ, Baldo M. Parasites of pigeons (Columba livia) in urban areas of Lages, Southern Brazil. Parasit Latinoam 2007; 62(3-4): 183-187.

Santos GGC, Matuella GA, Coraiola AM, Silva LCS, Lange RR, Santin E. Diseases of wild birds diagnosed at the Federal University of Paraná, Brazil (2003-2007). Pesq Vet Bras 2008; 28(11): 565-570. http://dx.doi. org/10.1590/S0100-736X2008001100005.

Snak A, Lenzi PF, Agostini KM, Delgado LE, Montanucci CR, Zabott MV. Coproparasitological analysis of captive wild birds. Cienc Anim Bras 2014; 15(4): 502-507. http://dx.doi.org/10.1590/1089-6891v15i425797.

Taylor MA, Coop RL, Wall RL. Parasitologia veterinária. 3rd ed. Rio de Janeiro: Guanabara Koogan; 2010.

Vicente JJ, Rodrigues HO, Gomes DC, Pinto RM. Brazilian nematodes. Part IV: nematodes of birds. Rev Bras Zool 1995; 12(S1): 1-273. http:// dx.doi.org/10.1590/S0101-81751995000500001.

Williams RB. Epidemiological aspects of the use of live anticoccidial vaccines for chickens. Int J Parasitol 1998; 28(7): 1089-1098. PMid:9724880. http://dx.doi.org/10.1016/S0020-7519(98)00066-6. 